\title{
Study on metaplastic lesions in gastric cancerogenesis
}

\author{
Vuka V Katic* \\ Policlinic Human, University of Nis, Serbia
}

\section{Introduction}

Gastric cancer remains the second most frequent cause of cancer- related deaths and ranks 4 th in cancer incidence worldwide [1-9]. Although mortality from gastric cancer has been declining in most countries, it stil represents a major health problem throughout the world, accounting for $7.8 \%$ of cancers worldwide [10-13]. Areas where incidence is high at $>$ 60 per 100.000 males include eastern Asia (Republic of Korea and Japan), eastern Europe and Central and Latin America [13-18]. The "intestinal" type of adenocarcinoma is relatively predominant in high - incidence regions of the world, whereas the "diffuse" type is relatively more common in low-incidence areas. The prognosis of GC varies depending on stages [3-7].

The 5-year survival rates for advanced gastric cancer are less than $20 \%$. On the contrary, early gastric cancer (EGC) makes a good prognosis that the 5-year survival rates are over $90 \%$ to $95 \%$ [6-12]. Therefore, it is important to individualize the management for high risk group of gastric cancer. The risk factors of gastric cancer are Helicobacter pylori infection, salt intake, smoking, alcohol, family history of gastric cancer and the main precursor lesions of the both atrophic gastritis (AG) and intestinal metaplasia (IM) [19-24]. H. pylori infection has been proved as the most important risk factor of AG and IM. So, AG is considered to be an ancestor to IM [13-30].

From this background, the aim of this review is to provide comprehensive information regarding the diagnosis and management of AG and IM and to establish strategies to prevent gastric cancer.

\section{Atrophic gastritis and Metaplasia, as Precursor Lesions of the gastric mucosa}

Chronic inflammation damages of inflamed cells triggers, a multistage carcinogenesis process [1-4,12-27]. These inflammatory cells contribute to cancer initiation, promotation and metastasis, by producting cytokines, reactive oxygen species and reactive ninitrogen species [2,18-20,25-30]. Damages of cellular components result in increased mutations and altered functions of important enzymes and proteins in premalignant tissues, so contributing to the multistage of carcinogenesis process [4,5-10,16-19,29-33].

Thus, the eradication of $\mathrm{H}$. pylori is the most important to prevent the progression (Figure 1). While dysplasia is a well recognized morphological marker of premalignant change in the gastric mucosa $[1-6,18]$, the role of IM in the histogenesis of GC is still a matter for debate [21-26].

In most text books metaplasia is defined as "a change from one type of differentiated tissue to another, normally differentiated type". The mechanisms of metaplastic transformation are still obscure.

\section{Aim}

In this chapter we focus on the heterogeneity of IM as indicated by morphological, histochemical, imunocytochemical and ultrastructural studies, providing the evidence for the IM - dysplasia - carcinoma sequence [7-10,11-16]. Based on a study of morphology, differentiation and mucin secretion, Jass and Filipe (1986) have identified three types of IM [2].

\section{Materials and methods}

During the period from 2013 to 2018, the 50 patients with autoimmune (A) Gastritis, (Figure 1), 50 patients with Helicobacter pylori + infectious (B) Gastritis, (Figure 2), as well as 20 patients in control group, had gastroscopy. Histopathological examinarion was done in

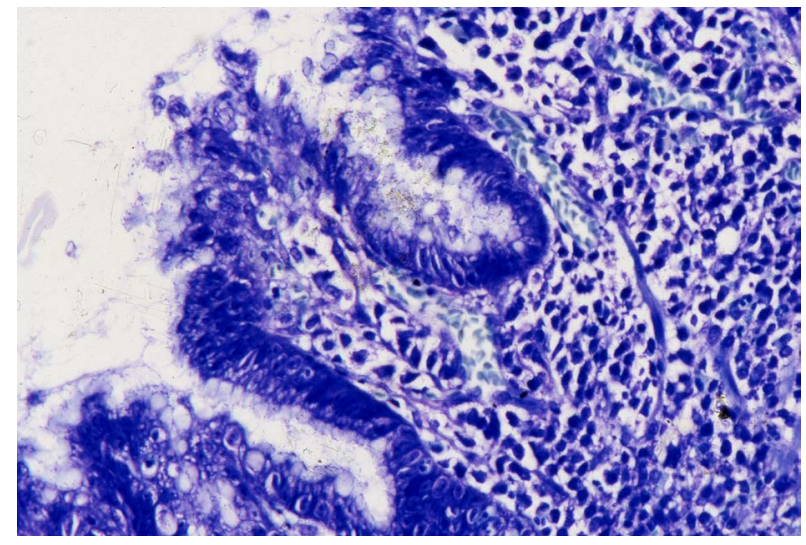

Figure 1. Helicobacter pylori B gastritis. Gimsa x 300 .

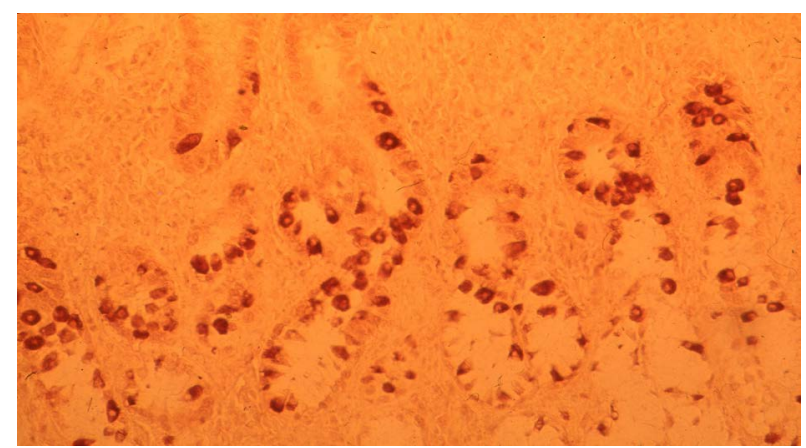

Figure 2. Autoimmune A gastritis: marked G-cell hyperplasia in antral mucosa. ABC x 300 .

${ }^{\star}$ Correspondence to: Vuka Katic, Policlinic Human, University of Nis, Serbia, Tel: +00381 18 533190; E-mail: vuka.katic@gmail.com

Received: April 16, 2018; Accepted: April 30, 2018; Published: May 4, 2018 
endoscopical biopsies of gastric antral and corpus/fundic mucosa and fixed in $10 \%$ formaldehyde. Paraffin sections were stained with classic HE, histochemical AB - PAS, HID-AB, Giemsa, argentaffine Masson reaction for analysis of enterochromaffine (EC) and argyrophilic Sevier Munger method for the discover of argirophilic enterochromafine-like (ECL) neuroendocrine cells. Immunohistochemical Avidine Biotin Complex $(\mathrm{ABC})$ method, with antibody to Gastrin, has been applied for the detection of neuuroendocrine Gastrin (G) cells. Basal Gastrin serum levels were examined by using Radio Immuno Assay (RIA) method.

\section{Results}

By analysis of endoscopically taken, processed and stained gastric biopsies, we are pointing out the following results:

Intestinal metaplasias, the most frequent preneoplastic lesions (Type I, II, III) of corpus/fundic localisation: in $86 \%$ of patients is associated with autoimmune (A gastritis):

Type I ( complete ): The epithelium consists of mature absorptive and goblet cells, as well as Paneth cells (Figure. 3). Villi and straight crypts lined by mature absorptive and goblet cells. On Alcian Blue PAS (AB-PAS) stain, the absorptive cells show a well formed brush border and are non - secreting. Goblet cells secrete sialomucin, as shown on HID -AB stain (Figure 4).

- EC cells: adenomatoid hyperplasia of argentaffine + cells, with black granules (Figure 5).

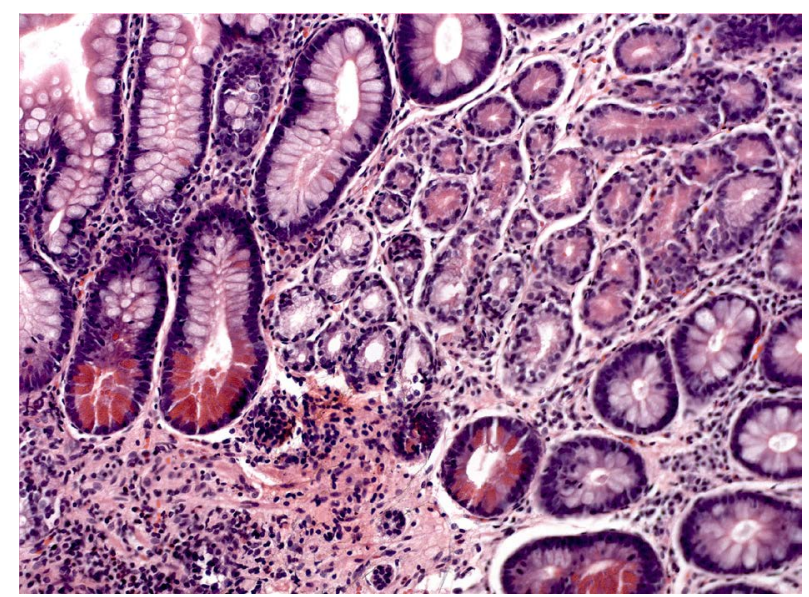

Figure 3. Intestinal metaplasia-complete type, with dominant Paneth cells (arrows) H\&E x 200 .

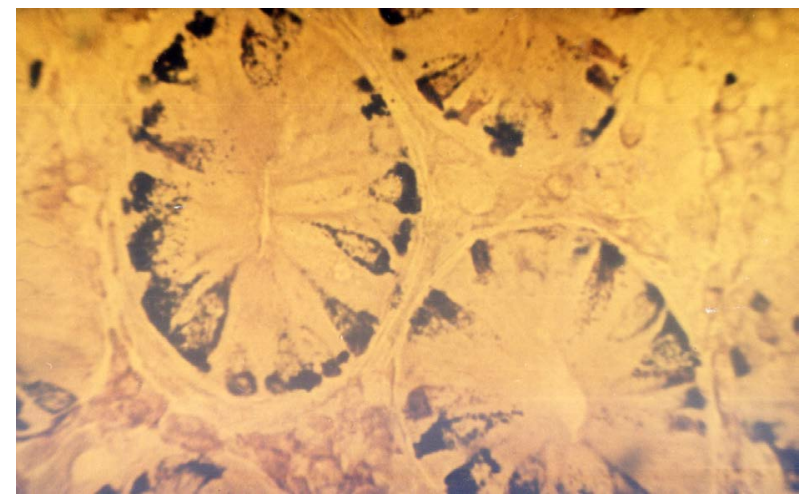

Figure 4. Intestinal metaplasia of neuroendocrine EC cells. Masson: Agentaffine reaction $\mathrm{x} 30$.

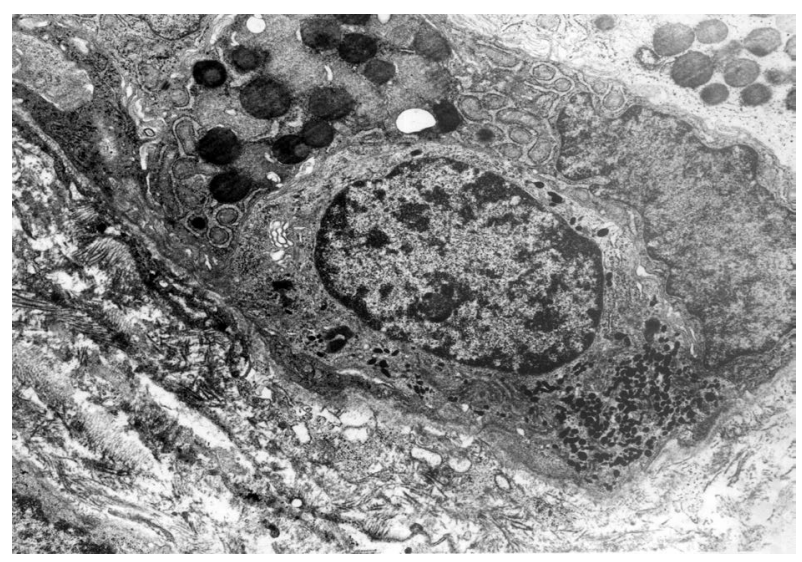

Figure 5. Complete IM: Endocrine EC-cell: Opened type Ultrastructural pattern.

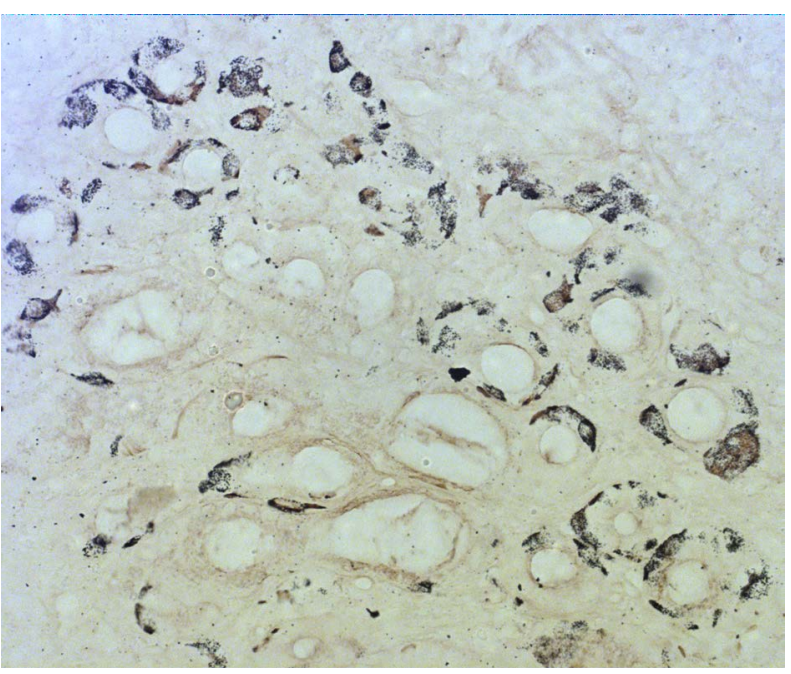

Figure 6a. ECL-cell hyperplasia, induced by hypergastrinemia. Sevier - Munger 200

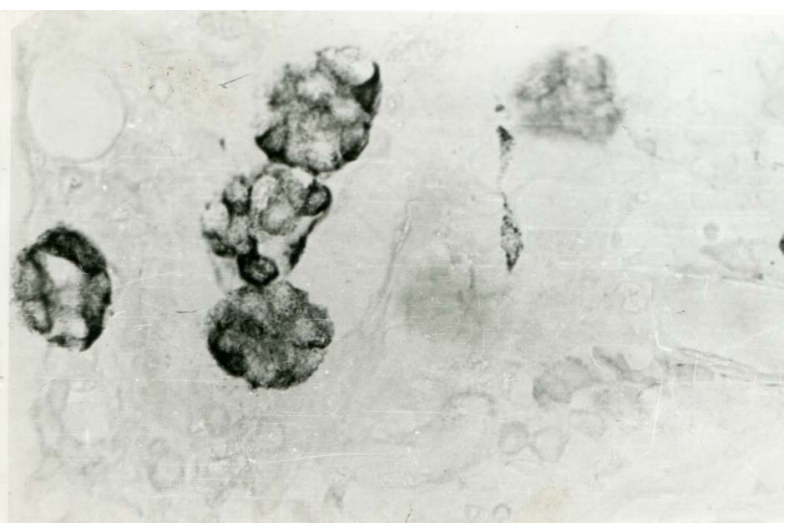

Figure 6b. Blackberry pattern of ECL cells. Sevier-Munger x 400

- Ultrastructural pattern: Gastric EC (closed) type has become Intestinal (opened) type (Figure 6a,b).

- Hyperplasia antral G cells (Figure 7) and metaplasia Corpus G cell inside of pyloric metaplastic fields) (Figure 8), associated with achlorhydria and hypergastrinaemia.

- Basal serum levels of Gastrin (Figure 9).

- Linear and blackbery ECL cell hyperplasia in fundic mucosa, associated with achlorhydria and hypegastrinaemia ( Figures 10 and 11a,b). 


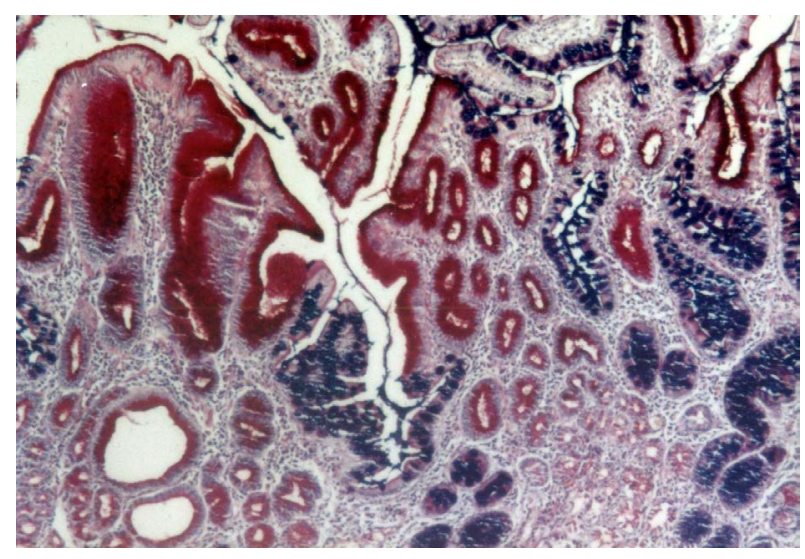

Figure 7. Gastritis with mixed: pyloric and intestinal metaplasia. AB-PAS x 200

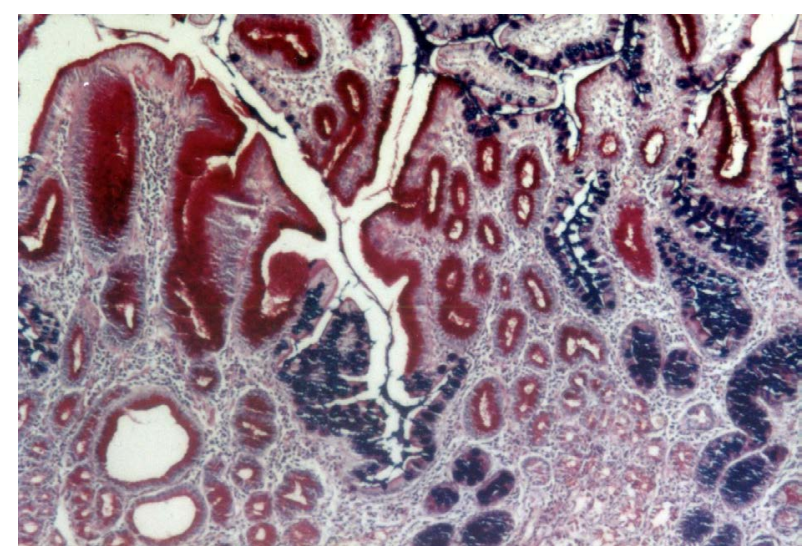

Figure 8. Combined pyloric (red) - intestinal (blue) metaplasia. AB - PAS x 200

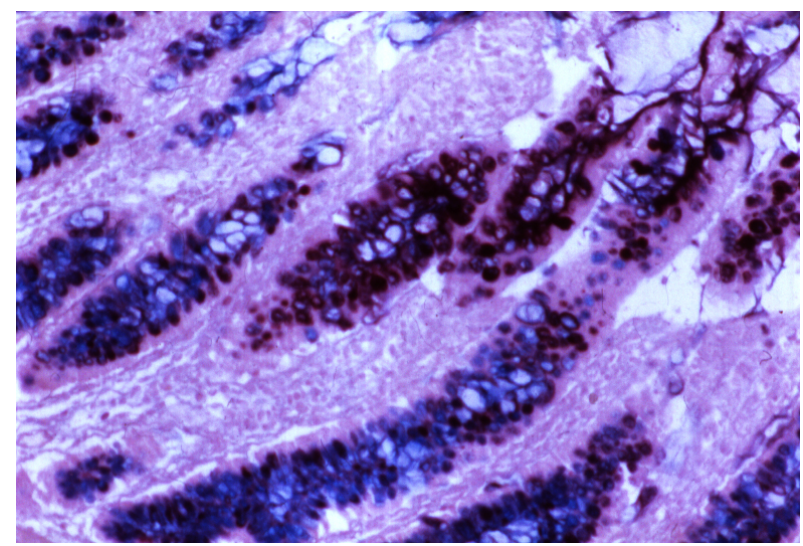

Figure 9. Intestinal incomplete metaplasia with predominant sialomucin (blue stain). HID$\mathrm{AB} \times 300$

Type II (incomplete): the crypts are elongated and tortuous. The epithelium is characteriyed by few or absent absorptive cells and the presence of columnar mucous cells in various stage of differentiation (Figure 12); the goblet cells secrete sialo- and occasionally sulphomucins (Figure 13). Paneth cells are rarely observed.

Type III (incomplete): distortion of glandular architecture is more pronounced and cell atypia and loss of differentiation is more marked than in type II. (Figure 14). Columnar cells secrete predominantly sulphomucins, and goblet cells contain sialo and/ or sulphomucins (Figures 15, 16 and 17). Paneht cells are usually absent. The highest value of cell heights being seen in type III. The presence of sulphomucin in goblet cells can be seen in any IM type, therefore i s not a criteria for a type III IM [2].

Forms of transition, both in terms of morphology and mucin profiles between these three principal variants are also noted, suggesting that IM heterogeneity and may reflect the stages in a dynamic process in which one form evolves to another, or regress [2]. The incomplete types remain unchanged and correspond to known types II and III. Sulphomucin + incomplete type (type III) is significantly associated with intestinal gastric carcinoma, whereas the sulphomucin negative incomplete type (type II) is more frequentrly seen in benign conditions [2]. By Jarvi and Lauren classification, gastric carcinomas are subclassified into tumours

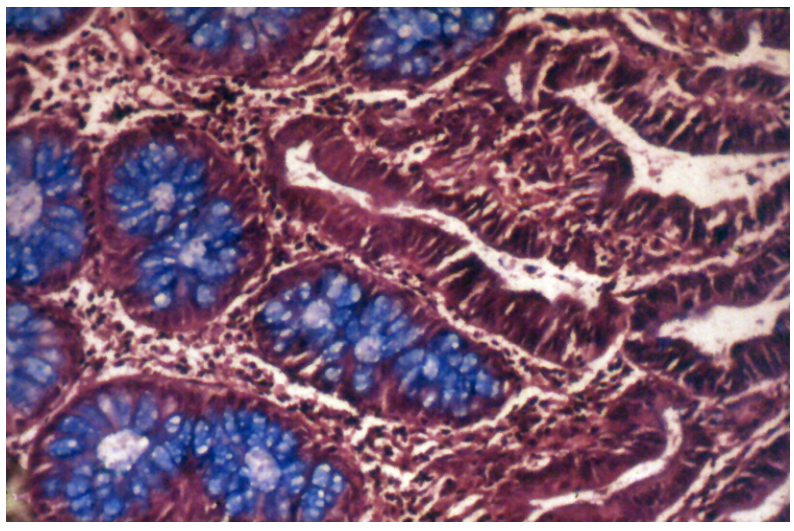

Figure 10. Intestinal inclomplete metaplasia, surouded by adenocarcinoma without mucin Type II. HID - AB x 300 .

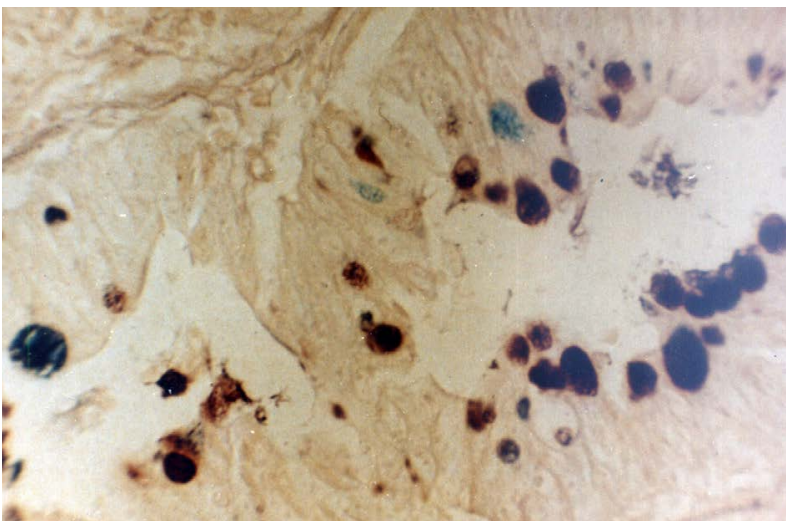

Figure 11a. Enterocolic metaplasia with sulphomucin - Type III. HID AB x 300

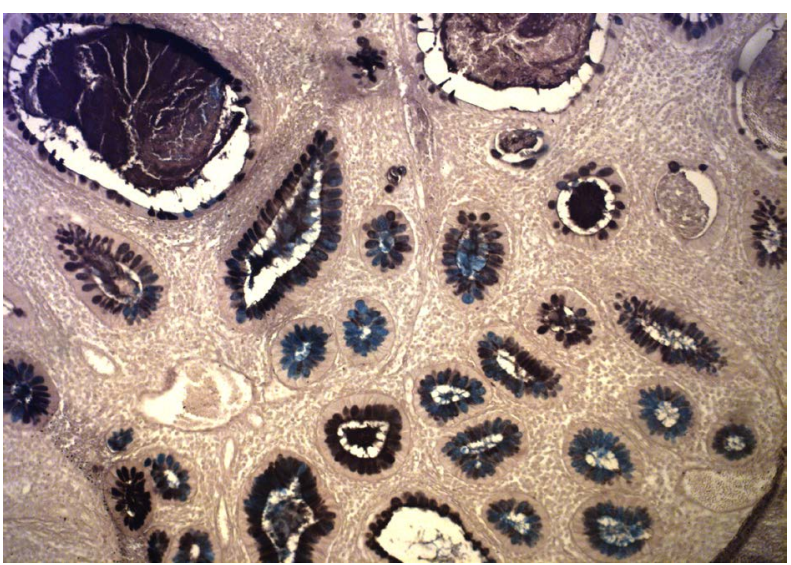

Figure 11b. B Gastritis: Enterocolic metaplasia (Type III) with Sulphomucin. HID-AB x 300 


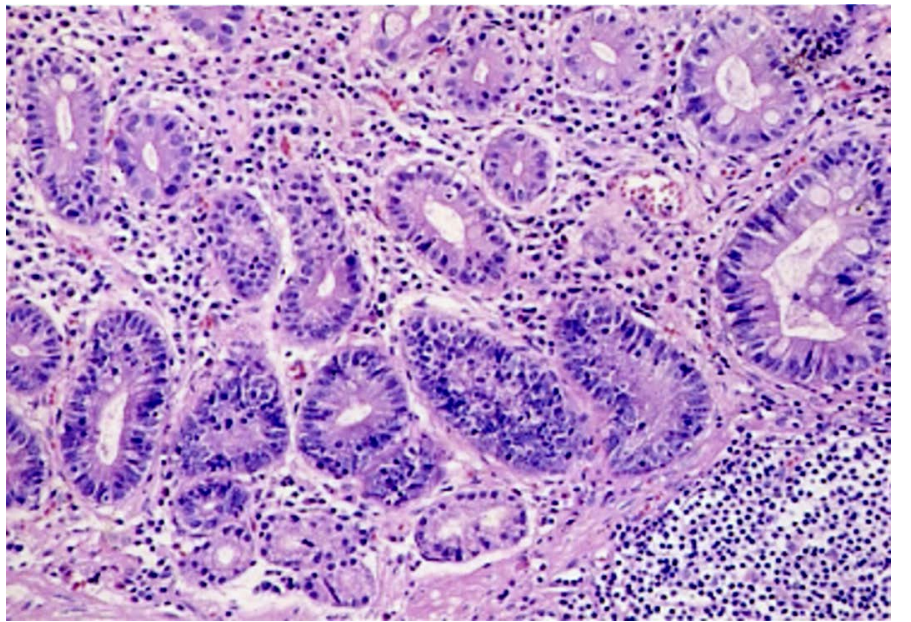

Figure 12. Dysplastic intestinal metaplasia. HE x 200

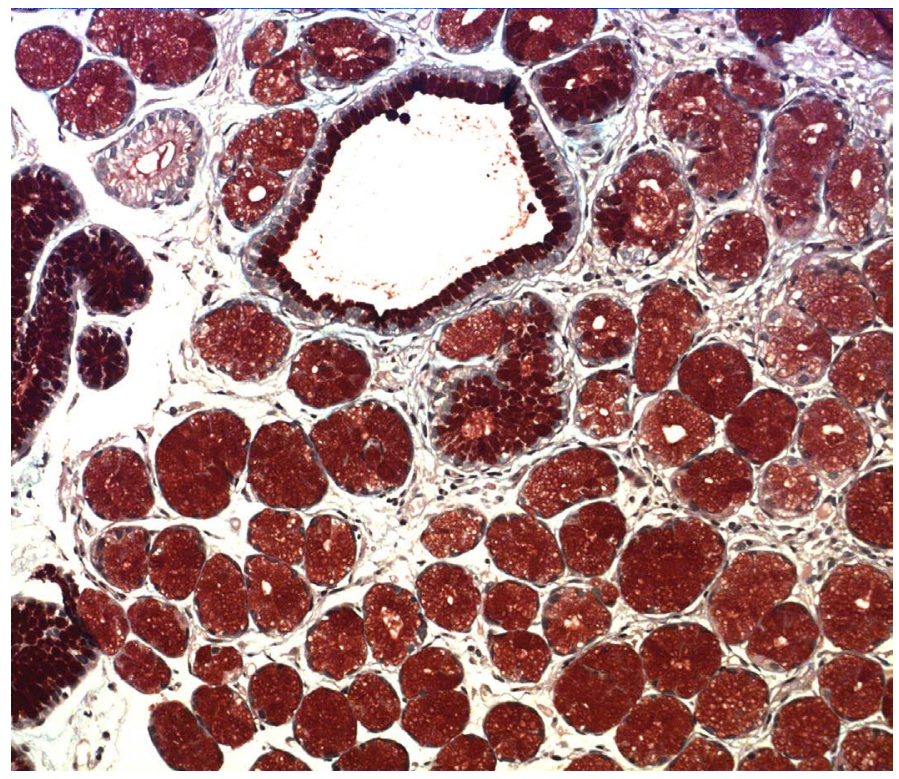

Figure 13. Predominant pyloric metaplasia with hipersecretio the neutral mucin AB-PAS x 300 neutral mucin

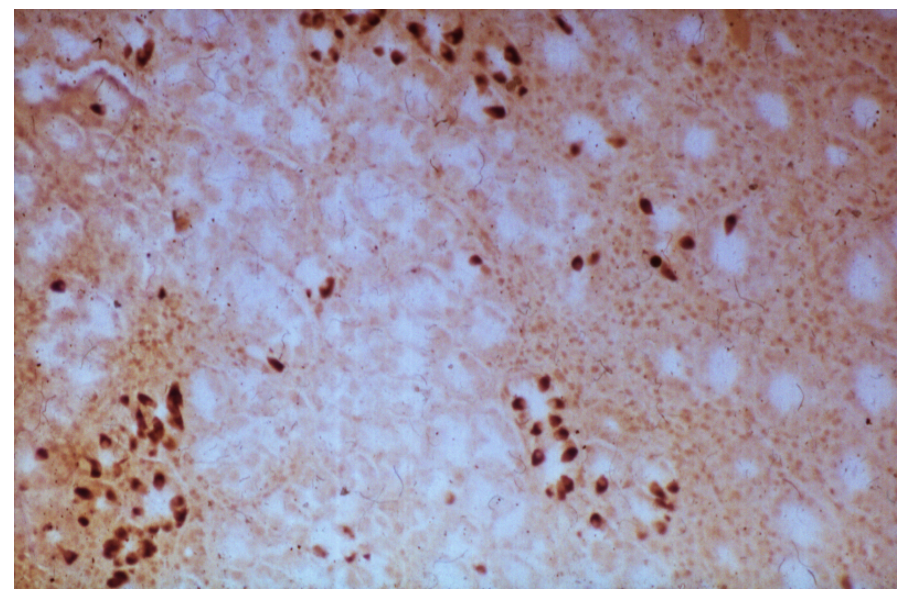

Figure 14. A gastritis: pyloric metaplasia with gastrin cells. PAP x 200

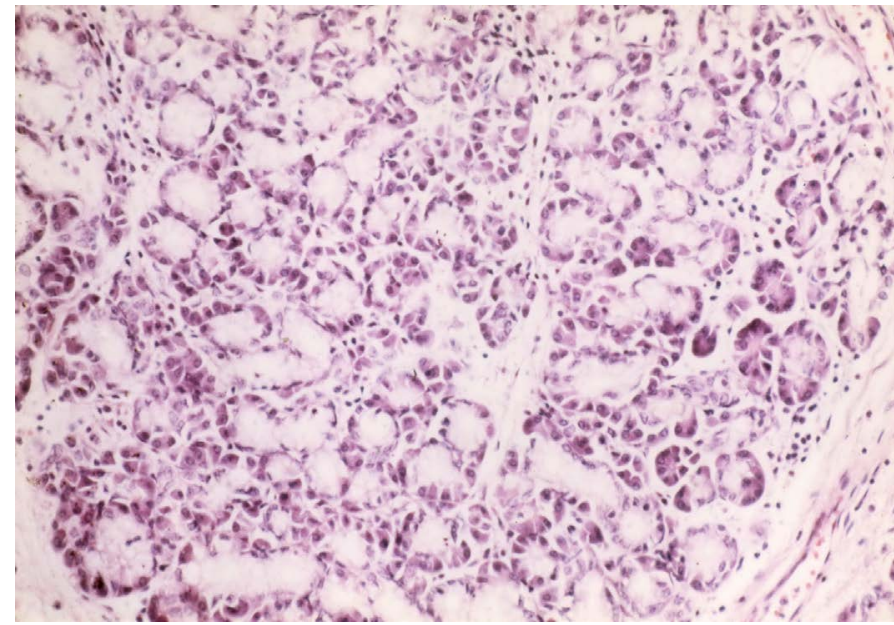

Figure 15. Exocrine lobular pancreatic structures in gastric antral mucosa. HE x 300

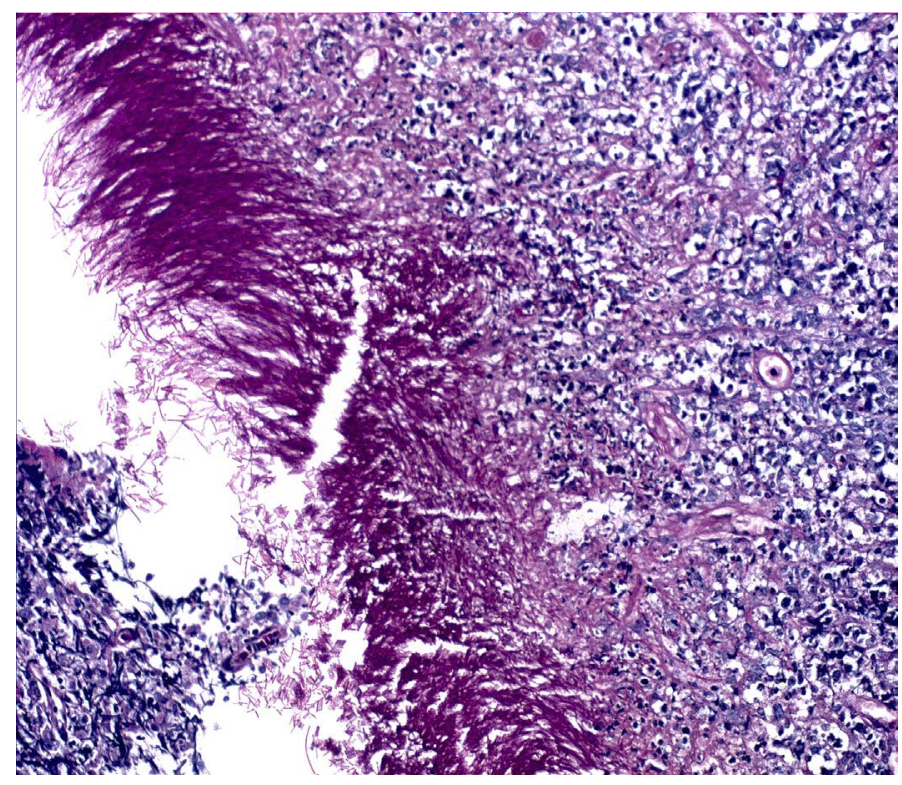

Figure 16. Micotic gastritis. PAS + hyphae

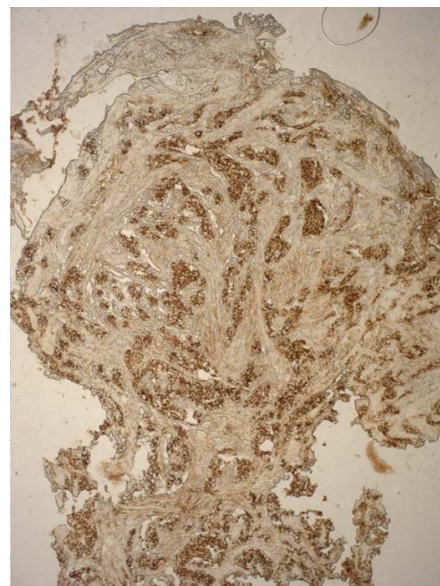

Figure 17. ECL- cell carcinoid: strong chromogranine A + reaction in neuroendocrine cells. ABC x 200 
with intestinal, gastric and mixed differentiation, by using gastric markers (mucins MUC5AC, MUC6), intestinal markers (MUC2), transcription factors (CDX2, CD10) and others, representing new chalenge for the researchers in the future $[1,10]$.

\section{Rare metaplasias in gastric mucosa}

Less knowh the role of Pyloric, and rarer Pancreatic as well as Cilliar metaplasia in the gastric mucosa, requests detailed studied in the future. Except wrong definition that pancreatic acinar metaplasia represents the nodules of normal pancreatic tissue up to $1 \mathrm{~cm}$ in gaster or intestinal mucosa. Sometimes these islands presented in submucosa or in muscularis propria, mixing in this way the process of "metaplasia" with hamartomatous "pancreas aberans" [32,33].

\section{Discussion}

\section{Mucin histochemistry}

Normal mucinous gastric cells secrete neutral mucins. The goblet cells of the complete and incomplete IM secrete acid mucins. In complete IM this includes $\mathrm{N}$ - and $\mathrm{O}$-acylated sialomucin and small amounts of sulphomucins. The columnar cells of complete IM resemble intestinal enterocytes and therefore do not secrete mucus. The columnar cells of incomplete IM secrete mainly neutral mucins or sulphomucins $[10,16]$. There is generaly an agreement that a variant of IM secreting a sulphomucins shows a selective association with gastric carcinoma, particularly the intestinal type $[8,10,11,15,18-20]$.

Sulphomucins are secreted also by gastric dysplasia and gastric carcinoma. Some authors have adopted the term "colonic" metaplasia to describe the sulphomucin digestion secreting variant of IM $[18,19]$. The secretion of sulphomucin may not so much indicate early neoplastic transformation, but rarely reflects cellular adaptation to a carcinogenic microenvironment [30-37]. However, the secretion of sulphomucin may represent an important cytoprotective mechanism. Secretion of sulphomucin may be linked in several ways to gastric carcinogenesis. Finally, neoplastic clones which are protected by the secretion of sulphomucin, may be better able to resist gastric acid.

\section{Metaplasia}

Metaplasia may be important signal of a potentially cancerogenic environment. In the stomach, metaplasia itself may undergo malignant transformation [1-7]. The first step involves chronic superficial gastritis, reversible lesion, induced by a variety irritant. Atrophy or loss of pariethal cell mass leads to hypochlorhydria and this allows the growth of bacteria which contain nitrate reductases which transform dietary nitrate to nitrite, a very active molecule which with the appropriate substrates may form $\mathrm{N}$-nitroso compounds in situ. Nitrate is ubiquitous in foods; most diets contain more than adequate amounts to enter in the reactions.

\section{Conclusions}

- Gastric cancer is still a major cause of death in our republic.

- H. pylory infection triggers a multistep inflammation from chronic gastritis, atrophic gastritis, IM and funally to gastric cancer.

- As the infection of H. pylory is the most important risk factor of AG and IM, it is important to perform $\mathrm{H}$. pylori eradication to prevent the progression to gastric cancer.

- However, side effects induced by eradication $H$. pylory therapy, are both mycotic gastritis and ECL- cell type I carcinoid of the corpus/ fundic localisation, requesting further researches.

\section{The proposed protocol}

The protocol has been in progress since 1981 in a multicentric study (Filipe et al.). The essential points are:

1. Sampling of various regions and multiple biopsies.

2. Two levels cut from each biopsy.

3. $\mathrm{H}$ and $\mathrm{E}$ and Alcian blue + PAS stain in each case. If incomplete IM is present, futher HID-AB stain is requested.

4. Report to the clinician to include IM types and advice for follow up according to protocol. A close relationship with the endoscopist is important as clinical as well as histological parameters will determine management.

\section{References}

1. Jarvi O, Lauren P (1951) On the role of the intestinal epithelium in the histogenesis of Gastric Cancer. Acta Pathol Microbiol Scand 29: 26-44.

2. Jass JR, Filipe I (1986) Gastric Carcinoma. Current problems in tumour pathology. Churchill Livingstone. London Melburn and New York.

3. Correa P, Cuello C, Dique E, Burbano LC, Garcia FT, et al. (1976) Gastric Cancer in Columbia. Natural history of precursor lesions. J Natl Cancer Inst 57: 1027-1035. [Crossref]

4. Katic V (1979) Histochemical study of endocrine cells (G, EC et ECL) and Mucus in gastric mucosa of the patients with peptic ulcer. Doctoalr Dissertation.

5. 1-265. Medical Faculty of Nis University, Nis, Yugoslavia - Serbia

6. Morson C, Dawson IMP (1979) Gastrointestinal Pathology, 2nd ed. Blackwell Scientific Publications, Oxford 110-150.

7. Katic V, Tasic T, Dimov D, Dimitrijevic J, Živkovic V, et al. (2004) Role of Helicobacter pylori infection in the development of gastric neoplasms. Military Medical and Pharmaceutical. Journal of Serbia 61: 405-411.

8. Katic V, Novakovic R, Lebeda D, Mihailovic D (1985) Yugoslavica Physiologica et Pharmacologica Acta 21: 239-248.

9. Bloom SR, Polak JM (1978) Gut hormones overview. Bloom, SR (ed): Gut Hormones Churchill Livingstone, London and New York.

10. Katic V, Dojcinov D, Sljivic R (1976) Activite aminopeptidasique dans la metaplasie intestinale et dans le cancer de 1 estomac. International Congress of Gastroenterology. Abstracts. Budapest, 201.

11. Katic V, Novakovic R, Vukasinovic R, Kutlesic C (1984) Study on gastrin and entrochromaffin- like endocrine cells in gastric mucosa of patients with peptic ulcer. Gastroenterohepatologic Archuve 4: 170-180.

12. Correa P (1988) A human model of gastric carcinogenesis. Cancer Res 48: 3554-3560. [Crossref]

13. Capella C, Solcia E, Snell K (1973) Ultrastructure of endocrine cells and argyrophi carcinoids of the stomach of praomus (mastomus) natalensis. $J$ of the Cancer Institute 50: 1471-1485.

14. Rotterdam H, Sommers Sh C, Waye J D (1981) Biopsy Diagnosis of the Digestive Tract, 490 .

15. Bordi C, Gabrielli M, Missalle G (1978) Pathologic changes of endocrine cells in chronic atrophic gastritis. Arch Pathol Lab Med 12: 129-135. [Crossref]

16. Bordi C, D'Adda T, Azzoni C, Pilato FP, Caruana P (1995) Hypergastrinemia and gastric enterochromaffin-like cells. Am J Surg Pathol 1: S8-19. [Crossref]

17. Rindi G, Luinnetti O, Cornaggia M, Capella C, Solcia E (1993) Three subtypes of gastric argyrophil carcinoid and the gastric neuroendocrine carcinoma: a clinicopathologic study. Gastroenterology 104: 994-1006. [Crossref]

18. Nakamura T, Nakano G (1985) Histopathological classification and malignant change in gastric polyps. J Clin Pathol 38: 754-764. [Crossref]

19. malignant change in gastric polyps. J Clin Patho 38: 54-64.

20. Polak JM, Coulling I, Doe E (1971) The G cells in pernicious anaemia. Gut 12: 319-323. 
21. Ming SC (1979) Dysplasia of gastric epithelium. Front Gastrointest Res 4: 164172. [Crossref]

22. Katic V (1989) Pathology of the Stomach - Monography. Medical Book BeogradZagreb. 1-231.

23. Hattori T, Helpap B, Gedigk P (1982) Regeneration of endocrine cells in the stomach. Virchows Arch B Cell Pathol Incl Mol Pathol 38: 283-290. [Crossref]

24. Hattori T (1986) Development of adenocarcinomas in the stomach. Cancer 57: 15281534. [Crossref]

25. Hattori T, Arizono N (1988) Cell Kinetics and Secretion of Mucus in the Gastrointestina Mucosa, and Their Diurnal Rhytm. J Clin Gastroenterol 10: 81-86. [Crossref]

26. Hattori T (2004) Histopathological and experimental studies on development of gastric cancers. Review article. Archive of Oncology 12: 3-6.

27. Lauwers GY, Carneiro F, Graham DZ, Gurado MP, Franceschi S, et al. (2010) Gastric carcinoma, p 48 - 58. In WHO Classification of Tumors of the Digestive System, Precursor and Premalignant lesions Edited by Bosman.

28. Garneiro F, Hruban RH, Theise ND (2010) International Agency for Research on Cancer, Lyon.

29. Gonsales CA, Sanz-Anquela JM, Gisbert JP, Correa P (2013) Utility of Subtiping intestinal Metaplasia as marker of gastric cancer risk. A reviev of the evidence. Int $J$ Cancer 133: 1023-1033. [Crossref]
30. Park YH, Kim N (2015) Review Atrophic Gastritis and Intestinal Metaplasia as a Premalignant Lesion of Gastric Cancer. J Cancer Prev 20: 25-40. [Crossref]

31. Liou G Y, Dooppler H, Nacela B, Krishna M, Crawford HC, et al. (2017) Macrophagesecreted cytokines drive pancreatic acinar- to -ductal metaplasia through NF-K.

32. Macukanovic - Golubovic L, Katic V, Rancic G, Milenovic M, Marjanovic G, Golubovic Z (2007) Study on histogenesis enterochromaffin-like carcinoid in autoimmune gastritis associated with pernicious anemia. Vojnosanit Pregl 64: 543-548. [Crossref]

33. Koukoulis GK, Ke Y, Henley JD, Cummings OW (2002) Detection of pyloric metaplasia may improve the biopsy diagnosis of Crohn's ileitis. $J$ Clin Gastroenterol 34: 141-143. [Crossref]

34. Kapadia CR (2003) Gastric atrophy, metaplasia, and dysplasia: a clinical perspective. $J$ Clin Gastroenterol 36: 29-36. [Crossref]

35. Katic V (2017) Study on Morphology and Pathogenesis of Type 1 ECL-Cell Gastric Carcinoids. Recent Studies on Digestive System Anatomy. Chapter 1.

36. Doglioni C, Laurino L, Dei Tos AP, De Boni M, Franzin G, et al. (1993) Pancreatic (acinaro-like cells) metaplasia of the gastric mucosa. Am J S Pathol 17: 1134-1143. [Crossref]

37. Mogonta L, Streba CT, Pirici D, Dîrnu R, Oprea B (2010) Pancreatic metaplasia of the gastric mucosa associated with gastroduodenal ulcer. Rom J Morphol Embryol 51: 365-369. [Crossref]

Copyright: $@ 2018$ Katic VV. This is an open-access article distributed under the terms of the Creative Commons Attribution License, which permits unrestricted use, distribution, and reproduction in any medium, provided the original author and source are credited. 